\title{
Model of Development of Ruhul Islam in Bandung Islamic University
}

\author{
${ }^{1} \mathrm{M}$. RACHMAT EFFENDI, ${ }^{2}$ EDI SETIADI, \\ ${ }^{1}$ Islamic Broadcasting Communication, Universitas Islam Bandung, e-mail. muhammadrahmateffendi@gmail.com \\ ${ }^{2}$ Law Faculty, Universitas Islam Bandung, e-mail 2edi_std@yahoo.co.id
}

\begin{abstract}
This study examines the quality of the development model of ruhul Islam and the increase in the diversity of lecturers and employees at Bandung Islamic University. The aim is to analyze the involvement of Unisba's lecturers and employees in the development of Ruhul Islam. This study uses a qualitative approach with phenomenological methods, while data collection techniques are carried out through participant observation, literature study, in-depth interviews, and Focus Group Discussions. The results show that: first, the policy of developing the so-called the Spirit of Islam is carried out consistently; second, the development of the Ruhul Islam model is implemented by increasing the diversity of lecturers and employees already in line with the tridharma of higher education; and third, increasing the diversity of lecturers and employees is carried out systematically through a special program by the Islamic Studies Institute. The level of diversity can affect the development of the Ruhul Islam in the end. This research can be used as a model by other Islamic universities and it is expected to contribute scientifically to the development of Islamic studies.
\end{abstract}

Keywords: development, lecturers and employees, ruhul islam

\section{Introduction}

Human life in the global era will be faced with two tremendous surprises/shocks in relation to physical and psychological dimension. The shock of physical dimension can be detected by science and technology and its impact can help human activities in developing and increasing their productivities. While, shock of a psychic dimension is a symptom related to human psychological condition. It is very dangerous and accordingly can threaten the survival of human civilization (Chakravartty, 2019). The ultimate therapy for humans who feel their state of life under threat is a spiritual touch through religious messages that will become a necessity. The global era can be predicted to be an era of spiritual awakening since people who live in the global era will feel bored by the storms of the lifestyles of globalization, such as glamorous, hedonism and etc (John Nisbitt and Patrisia Abuderne in Zulkifli, 2007) The ideologies such as socialist, communist and capitalist until now do not seem to be able to solve the problems of humanity as the consequences of advance in science, technology and art. The science and technology which are mentioned above are based on the freedom of value or, in other word, value-free that has a negative impact on human life. In such a condition, a man will look for a thing so called zeal and a tendency to seek spiritual coolness (Setiadi, 2018). The existence of Islamic institutions is very important because from Islamic point of view, Islamic universities are the heart of civilization which is expected to be able to develop the values of Ruhul Islam (the spirit of Islam) through the organization of higher education.

In Islamic education, the spirit of Islam aims to develop the human personality as

Received: March 02, 2021, Revision: April 18, 2021, Accepted: June 02, 2021

Print ISSN: 0215-8175; Online ISSN: 2303-2499. DOI: https://doi.org/10.29313/mimbar.v37i1.7689

Accredited Sinta 2 based on the decree No.10/E/KPT/2019 until 2024. Indexed by DOAJ, Sinta, Garuda, Crossreff, Dimensions 
a whole and in balance through the training of the soul, intellect, rationality, feelings and body senses. All aspects are combined in the education system holistically towards goodness and the attainment of perfection and are devoted entirely to Allah alone (Firdaus, 2013).

At this level, Islamic universities should be able to develop the values of Islamic spirit through the Tridarma of Higher Education since the values of Islamic spirit are the basis for all activities, supporting knowledge and soft skills that penetrated into every dimension of life, shaping and coloring culture and instilling basic principles as a view of human life (Effendi: 2020).

The level of religiosity has an interdependence relationship with the development of Islamic Spirit. The higher the level of religiosity, the higher the spiritual system, which is manifested in the form of akhlakul karimah consistently (Jamal, Yaccob, Bartikowski, \& Slater, 2019) since "every worship activity that is right will affect the upholding of morals and cleanliness of the soul" (Ridla, $1373 \mathrm{H}$ ).

Universitas Islam Bandung (UNISBA) as private university of Islam in Bandung, Jawa Barat, was established with the aim to (1) produce a well-educated man who has potential as Mujahid (warrior), Mujtahid (thinker/researcher), and Mujaddid (reformer); (2) generate an new findings in the fields of science, technology, and art that are beneficial to Ummah, society, nation, and state through various research activities; (3) to develop an orderly dynamic physical and social environment as part of a society that is just, prosperous, and being committed to the rules of commandment of Allah SWT; (4) to uphold the values of Islamic teaching peacefully to individuals, families, communities, as well as to the nation, and the state (Statuta UNISBA, 1958 - 2016). At this level, the degree of lecturers' religiosity became significantly important in the development of the values of Ruhul Islam in UNISBA because lecturers are the most important component of education, the forefront of serving students and the other community as well. The issues bring in this research: what is the policy of UNISBA on the development of the Ruhul Islam and at what level of reality the lecturers' religiosity is and how far the influence of the Unisba lecturers' religiosity on the development of the Ruhul Islam to the people inside and/or outside the campus.

The policy is a formal written rule to regulate people's behavior in increasing substantial benefits as an effort to create new values in the organization (Alcántara, Klesges, Resnicow, Stone, \& Davidson, 2015). This formal decision is used as the main reference in organizational behavior. Therefore, policy is a projected objective in considering changing dynamic relationships among the various components. And in practice, it is not specific to just one social function. (Yamaguchi,2018). While the values derive from a social construct that are rooted in language which lends sit self to interpret from a narrative perspective (Green \& Sergeeva, 2019), and direct practices (Caputo, Ayoko, Amoo, \& Menke, 2019)employees and people at large are often required to engage in cross-cultural negotiations. In this regard, it becomes important for negotiators to develop the ability to recognize cultural differences and adapt their negotiation styles to the cultural contingencies they face. This study examines the influence of cultural intelligence on the relationship between cultural values and the individual preferences for a given negotiation style. Our results show that cultural values (e.g. power distance, uncertainty avoidance, collectivism and masculinity.

Four important variables that must be considered in implementing the policy: (a) optimizing state-of-the-art communication for security and performance improvement (Jang \& Kang, 2019), (Jang \& Kang, 2019); (b) resources that refer to human resources which play a major role in the fulfillment of organizational vision (Aviso et al., 2019); (c) information where some kind of information should be given smoothly for the importance of information argumentation generally (Kamimura, 2019); (d) disposition which is caused by a combination of two psychological factors; and (e) bureaucratic structure.

The policy of Islamic universities is not only focused on increasing the productivity of the institution which results in positive effects on the performance of the product, but also having to build policies that is related to the production of people who fear God. The learning efforts that only focused on the increase of organizational productivity and not related to the production of a godfearing person would not be enough in the 
would-be Human Resource Development framework of Islam (Muhammad Fauzi: 2014).

The word religiosity is taken from the word religious (English) and religio, religare or religere (Latin) which means religious commitment that is realized and can be seen in the form of individual religious behavior.

The term religiosity means diversity to obey (obedience) to religion and is taken from the word religious ( $=$ religious in nature) that derived from the word religion (Latin: religio, religare or religere, which is often interpreted asAgama (Sankskerta) and Dien (Arabic). From this understanding of language, it can be understood that religiosity is a religious commitment that can be seen in the form of individual behavior in religion (Effendi, 2018),

In connection with the above definition, Effendi (2018) formulates five dimensions of diversity according to Glock and Starke: (1) Religious Belief (The Ideological Dimension) is the degree to which a person accepts dogmatic things as a process of examining potential differences in religious dogmatism, comprising the doctrine of trust which is the most basic that distinguish one religion from another (Schnabel, 2018). (2) Religious Practice such as prayer, worship, and fellowship which have been shown to support feelings of connectedness and behaviors acting as a potential reinforcing influence on positive mental health outcomes provided (The Ritualistic Dimension) (You, Yoo, \& Koh, 2019), that the degree is which a person performs ritual obligations in his religion. Ritual obligations are mentioned such as the procedures for worship and special rituals both on holy days or religious holidays. (3) Religious Feeling (The Experiential Dimension) is like superstition and the rituals as well which are used to support such beliefs that will remain as an important part of takhayul society; it, is the level of feelings or religious experiences that have been experienced and felt by someone. In other word, as the psychologist called it, religious experience (Daradjat, 1993). (4) Religious Knowledge (The Intellectual Dimension) or the expressions of religious systems which can occur through communicating religious value systems is the level of knowledge possessed about the teachings of the religion that he adheres to complete knowledge of the Al-Qur'an and various ritual practices or worship and muamalah, as well as Islamic civilization. (5) Religious Effect (The Consequential Dimension) is the degree to which a person's behavior is motivated by religious teachings (Setiadi, 2018).

According to Ancok (1994:80), the dimensions of religiosity formulated by Glock and Starke can be aligned with the Islamic teaching system, although not entirely the same. For example, the ideological dimension, which can be equated with faith or 'aqidah; ritual dimension, which can be equated with shari'ah or worship; experiential dimension, which can be equated with mysticism; the intellectual dimension (knowledge), which can be equated with Islamic thought that plays a very important role in the perfection of other dimensions; whereas, the consequential dimension has a meaning parallel to morals and is the embodiment of other dimensions in the form of religious behavior. Thus, the meaning of religiosity is a comprehensive and complete religious nature, so that the Qur'an calls on believers to be obedient to Allah SWT in a "kaffah".

The concept of religiosity is a detailed and comprehensive concept and can be used to explain the strength of 'aqidah, consistency of worship, depth of appreciation, breadth of knowledge, and the power of motivation in encouraging behavior. It contains intrinsic and extrinsic aspects, intrinsic social, and extrinsic social (Warren, 1977).

The study of religiosity in this study describes a person's mental condition in understanding, living and practicing the teachings of his religion since the awareness in religion is influenced by factors of intelligence, feelings, motivation, life experience, and socio-cultural conditions. The study of religiosity positions religious adherents to become fully religious people.

The level of religiosity is the level of human attachment to the religion he adheres to. In this case, a relatively high level of religiosity tends to carry out religious rules and obligations as well as life tasks (Warren, 1977).

The word ruh, which is mentioned twenty-four times in the Qur'an (Abdul Baaqy: t.t) covers various contexts and has a very broad meaning. In the human 
context, it is associated with the creation of Prophet Adam, a person with noble qualities and always follows the truth (Najati, 1992). This study is more directed at the context of the application of the spirit of Islam (Al-waahidi, II, 1415 H./1994M: 480), which is aligned with the attitude of ukhuwah Islamiyah as an identity or characteristic of an Islamic institution. Shari'ah and cultural values that have been rooted in society will stimulate the power of motivation, and even become agents that drive all community activities to be productive, efficient, futuristic, and have networking through the community. Thus, the spirit of Islam is the strength of Islamic values that encourage real behavior in life.

\section{Research Methodology}

This study used a qualitative approach taken from "Qualitative Inquiry and Research Design by (Lewis, 2015). It is an approach that reminds the subjects of research about their understanding on the phenomenon or things they experienced, such as behavior, perceptions, motivations, actions, etc. In other words, it is a holistic manner perspective on how to describe things in the form of words and language at the special natural context and also at the various natural methods. The data collected is primary data obtained from direct field such as a participant observation, literature study, in-depth interviews, and Focus Group Discussions (FGD), which is combined with document data (statutes, employment regulation, work plan, and manuals, as well as periodic reports of the Rector of Islamic University of Bandung (UNISBA) including various research conducted by previous researchers. The data collection techniques are conducted through the observation of participants and Focus Group Discussion (FGD) consisting of leaders of the foundation, Rector, representatives of the Rector, dean, leaders of institutions, leaders of the study program, the head of field at the university level, and stakeholders. In-depth interviews are also conducted to complete the data.

\section{Results and Discussions}

\section{The Policy of Unisba's Ruhul Islam}

The data obtained in the field show that UNISBA's policy on the development of the Islamic Spirit is written in a formal and binding decision. The goal is to regulate institutional behavior, such as functions, duties, positions and management. A formal decision involves the entire academic community in order to create Islamic values in various activities both internally on campus and externally in the community. Policies are written in the Articles of Association, Employment Regulations, and the UNISBA Strategic Plan as a basic reference in developing the Islamic Spirit.

All policies are aligned with the objectives of the establishment of UNISBA, especially in preparing Indonesian people who are educated, responsible for religion, nation, state, and humanity and benefit. The policy is based on the desire to uphold the values of the Ruhul Islam consistently, committed, and adaptively.

The policy of instilling the values of the Islamic spirit is carried out in two stages, namely the stage of enforcing the spirit of Islam starting from the establishment of Unisba in 1957 until 2000, and the stage of developing the spirit of Islam in 2000 until now (2021).

Periodically, in the period of 1957-1970, the enforcement of the values of Ruhul Islam was directed at the values of struggle based on sincerity. For example, lecturers did not get a salary and students were not charged tuition fees. During this period, there was a wish to apply the values of Ruhul Islam in the broadest sense. In 1970-1985, Unisba was expanded into a modern university and organized networks with umaro and ulama as well as the wider Muslim ummah by positioning Unisba as an institution belonging to all Muslims, becoming a pioneer in the renewal of Private Islamic Universities by establishing a Cooperation Agency between Private Islamic Universities. In 1986-1995, it held new student Islamic Boarding Schools and Undergraduate Boarding Schools; reaffirmed as a campus of struggle. In 19962000 , it took the initiative to organize Eid prayers and gatherings on an institutional basis.

In the next stage, since 2000, Ruhul Islam began to be developed by issuing Decree number 306/F.04/I/2002 concerning Procedures for Polite and Islamic Dressing, increasing the capacity of worship through Umrah and Hajj for lecturers and employees who have met the requirements, improve 
the atmosphere of worship on campus, pray before and after lectures, read the Qur'an before starting the lectures. Next was improving the understanding of Islam for staff and lecturers through the study of Qur'anic interpretation, conduct a strict selection of employees and lecturers, and finally, increasing the religious commitment of the academic community in carrying out their daily tasks.

Policy implementation is essential for the effectiveness of the organization of an institution as the authority and responsibility of management. The policy of developing the spirit of Islam is implemented through the university's Tri Dharma activities: Education \& Teaching, Research and Community Service. The goal is to produce graduates who are predicated as Mujahid (warriors), Mujtahid (researchers), and Mujaddid (reformers). The expected graduates are qualified and competitive, have a balance of intellectual, emotional and social competencies, responsive to scientific developments, and capable of building thoughts, ideas, theories and technology based on Islamic values. In social life, they are expected to be able to build a conducive and adaptive environmental system along with the times.

In order to achieve the goals effectively and efficiently, the Rector's Regulation number 428/C.12/Rek.XII/2014 was issued concerning Guidelines for the Improvement and Development of the quality of the Islamic Spirit. Its activities are coordinated by the Institute for Islamic Studies and Personality Development (LSI-PK) as a strategic and prestigious institution in managing the policy of developing the spirit of Islam in UNISBA.

LSIPK as an institution originally called the Institute for Islamic Studies (LSI) as a result of a workshop on August 21, 2008 in Bandung, based on Statute VI, UNISBA article 59 paragraphs (1) and (5), has a function to develop Islamic concepts. LSI also conducts studies, both theoretical and academic in the development of Islamic and Basic Sciences, as well as contextual Islamic practical thinking. It also has dialogic nuance, prestigious, total, integral, and holistic in an Islamic framework platform. It is a place for religious thinkers, a place for religious studies that is universal.

The results of participatory observations in the field show that LSI-PK has a very important role in improving the quality of understanding and practice of Ruhul Islam for lecturers and educational staff at Unisba. Since the vision, mission and goals rest on Islam itself, thus, LSI-PK functions to develop Islamic studies and personality development for the Unisba academic community.

Islamic studies are carried out through: (1) the learning process of Islamic Religious Education and Islamic boarding schools for students; (2) Fatwa and mosque management for the entire Unisba academic community and the general public. While the development of divinity is carried out through learning Citizenship and Language education.

The Islamic religious learning process is carried out formally through curricular for seven semesters and Islamic boarding schools with the nomenclature as follows: PAI-1 ('Aqidah); PAI-2 (Worship and Read and Write the Qur'an); PAI-3 (Muamalah); PAI-4 (Morals); PAI-5 (History and Islamic Civilization); PAI-6 (Islamic Thought); and PAI-7 (Islam in Discipline of Science). The Pesantren program is given in the second semester for one week located at Ciburial Campus II for prospective graduates and prospective doctors before going into the field. Those who have passed are given certificates and those who have not are given special guidance until they are declared to have passed.

The increase in diversity for lecturers is carried out through studies in each faculty coordinated by LSI-PK. Whereas for employees, special guidance is carried out through the study of Al-Qur'an and AlHadith, and general recitation at the AlAsy'ari UNISBA mosque once a week (every Wednesday).

\section{The Degree of Religiosity of UNISBA Lecturer}

The degree of religiosity refers to the quality or condition of a person in understanding, internalizing, and practicing the rules of religion that he has and displayed with total obedience. A person's relatively high level of religiosity tends to be able to fulfill obligations according to the rules in full. In the context of religious commitment of UNISBA lecturers, it can be seen from five dimensions as stated by the Glock above, namely first, Religious Belief (The Ideological Dimension), the degree to which a person accepts dogmatic things in his/her religion. The doctrine of trust 
is the most basic that can distinguish one religion from another. Second, Religious Practice (The Ritualistic Dimension), the degree to which a person performs ritual obligations in his religion, such as the procedures for worship and special rituals both on holy days and religious holidays. Third, Religious Feeling (The Experiential Dimension), the level of feelings or religious experiences that have been experienced and felt by someone, in terms of Psychology it is called a religious experience. Fourth, Religious Knowledge (The Intellectual Dimension), the level of knowledge about the teachings of religion that he adheres to complete knowledge of the Al-Qur'an and various ritual practices or worship and muamalah, as well as Islamic civilization. Fifth, Religious Effect (The Consecquental Dimension), the degree to which a person's behavior is motivated by religious teachings.

Based on the findings of the study with respect to the five dimensions of religiosity above, the degree of religiosity of UNISBA lecturers tends to still need to be improved. Of these five dimensions, the three-dimensional point of (a) Religious Belief, (b) Religious Practice, and (c) Religious Feeling tend to be high enough in the value range of 80 . In these two dimensions, in some respects, there is still a tendency of "no-sync" between beliefs in Allah and His Rasul (Prophet) with practical religious rituals performed. While the next two-dimensional point of (d) Religious Knowledge and (e) The Religious Effect are still below the numeric range of the value of 70 . From these two dimensions, there is interest found in the development of science, discipline, honesty and innovation, which is still relatively needed to be improved.

\section{The Influence of Religiosity on the development of Ruhul Islam}

The development of Ruhul Islam is the commitment of UNISBA in providing good service to the students and society. In the policies of the academic implementation, UNISBA apply Islam as "the ultimate concern". Thus, the Ruhul Islam in UNISBA is used as a direction and target that is distinguished from aspects, in which target uses specific features and support for the development of the academic community. Meanwhile, the Ruhul Islam regarding religious values is transmitted through the educational process that will give a great impact on the day to day and it seems to be a human being strongest anchor, and being an original inhabitant as well. These could be considered as a positive aspect, although the aspect of religious education is still an issue to be discusses in this context. In other word, all these aspects will represent the fundamental of our interest for the topic of this paper. The UNISBA academic community is committed that the Ruhul Islam is used as the basis for higher education tridharma activities, supporting knowledge and soft skills, then internalized and transferred to all students. Thus, the target of achieving Unisba's vision, mission and goals is effective (Effendi, 2014).

Based on research findings, the level of lecturers' religiosity had significant influence on the development of the Ruhul Islam. This means that the higher the level of lecturers' religiosity, the more effective the development of Islam in UNISBA. The supporting factor in the development of the Ruhul Islam and the increase in religiosity in UNISBA is the policy that has been outlined in the UNISBA Management system clearly (statutes, employment regulations, and UNISBA work plans), which is then supported by an adequate amount of available facilities. Meanwhile, the most prominent inhibitory factor is yet to grow the soul of fraternity as a whole from each of academic community in UNISBA. In addition, interest in the development of religious studies relatively still needs to be improved.

\section{Conclusions}

Based on the acquisition of literature, documentation and field data, it can be concluded that the Islamic Spirit at UNISBA is used as the basis for the tri dharma activities of higher education, served as a support for knowledge and soft skills. The entire component of UNISBA agreed that a purest Islam must be a commitment to the academic community of UNISBA to be transferred and internalized to all students in order to achieve the target of vision, mission and objectives of UNISBA. Although in the level of practice, especially with regards to the degree of lecturers' religiosity, it still has to be improved since based on data obtained the level 
of lecturers' religiosity had significant influence on the development of the Ruhul Islam in UNISBA. UNISBA's policy on increasing the religiosity of the academic community and development of Ruhul Islam remained consistent, committed and accommodating. UNISBA lecturers numbering about 511 people are entirely a Muslim, but their level of religiosity still relatively varied and needs to be improved.

Religiosity research can enrich the knowledge in particular religion (religious studies) and can contribute to other disciplines that have been established. Therefore, research on religiosity should be developed again through cultural themes of society with collaborative and interdisciplinary research in order to produce more comprehensive and in-depth findings about Religiosity, especially for the overall UNISBA academic communities (students, lecturers, and staffs). Similarly, researchers are expected to continue and deepen their similar research (Religiosity) since this kind of research is very important, considering the social phenomenon in the global era that tends to center on self/ego.

\section{Acknowledgments}

This research is made possible by the supports of Ministry of Research, Technology and Higher Education of the Republic of Indonesia and Universitas Islam Bandung. This article is the output of a research grant in 2019 .

\section{References}

Abdul Baaqy, Muhammad Fu'ad (t.t), AlMu'jam al-Mufahras Lialfaadlil Qu'an alKarim, Maktabah Dahlan, Indonesia

Alcántara, C., Klesges, L. M., Resnicow, K., Stone, A., \& Davidson, K. W. (2015). Enhancing the Evidence for Behavioral Counseling: A Perspective From the Society of Behavioral Medicine. American Journal of Preventive Medicine, 49(3), S184-S193. https://doi.org/10.1016/j. amepre.2015.05.015

Alwahidi, Majid Abu Al-Hasan Alie ibn Ahmad bin Muhammad bin Ali (1415 H./1994M.), Tafsir Al-Wasith Fi tafsiril Qur'anil:II, Darul Kitab Al-Alamiyah, Beirut Libanon, Ancok D Suroso FN, (1994), Psikologi Islam Solusiantara Problem-Problem Psikologi, (Yogjakarta: PustakaPelajar..
Aviso, K. B., Chiu, A. S. F., Demeterio, F. P. A., Lucas, R. I. G., Tseng, M. L., \& Tan, R. R. (2019). Optimal human resource planning with P-graph for universities undergoing transition. Journal of Cleaner Production, 224, 811-822. https://doi. org/10.1016/j.jclepro.2019.03.213

Caputo, A., Ayoko, O. B., Amoo, N., \& Menke, C. (2019). The relationship between cultural values, cultural intelligence and negotiation styles. Journal of Business Research, 99(September 2018), 23-36. https://doi.org/10.1016/j. jbusres.2019.02.011

Chakravartty, Anjan. (2019). Physics, metaphysics, dispositions, and symmetries - À la French. Studies in History and Philosophy of Science Part A, 74, 10-15. https://doi.org/10.1016/j. shpsa.2018.12.006

Daradjat, Zakiyah. 1993. Pengantar IImu Jiwa Agama. Jakarta: Bulan Bintang.

Edi Setiadi, (2018), Religiosity Improvement and Development of Ruhul Islam (Case Study of Lecturers and Education Personnel in Universitas Islam Bandung), Internasional Journal AL-ABQARIY, Journal of Islamic Social Sciences and Humanity, USIM Malaysia; VOL. 22 (2); 2020-07-08, pp 8-20, https:// abqarijournal.usim.edu.my/index.php/ abqari/article/view/319

Edi Setiadi, (2018), THE DEVELOPMENT POLICY OF RUHUL ISLAM AND THE RELIGIUSITY IMPROVEMENT, Proceeding of Social and Humaniora Research Symposium (SoRes) LPPM Unisba' Vol.307. 22-23 Oktober 2018; Available Online March 2019. Hal.350; ISSN.23525398; Atlantik Press; https:// www.atlantis-press.com/proceedings/ sores-18/55915351

Effendi, M. Rachmat, (2020). The Local Wisdom Based On Religious Values A Case Of Indigenous People In Indonesia, Internasional Journal of Humanities \& Social Sciences Reviews eISSN: 2395-6518, Vol 8, No 3, 2020, pp 1395-1404, https://giapjournals. com/hssr/article/view/4396

Effendi, M. Rachmat, (2018), (Interdisciplinary Journal of Communication), Vol.3, No.1, Juni 2018: h. 125-146, p-ISSN:2548-5857; e-ISSN:2548-7124; https://www. neliti.com/id/publications/270443/ religiusitas-masyarakat-adat-kampungdukuh-kabupaten-garut-jawa-barat

Effendi, M. Rachmat, (2014), PERANAN 
DA'I DALAM MEREKATKAN UKHUWAH ISLAMIYAH, Prosiding SNaPP2014, Sosial, Ekonomi dan Humaniora I S S N 2089 -3590, EISSN2303-

Firdaus, RaudlotulBinti Fatah Yasin, (2013), Islamic Education: The Philosophy, Aim, and Main Features, International Journal of Education and Research, Vol. 1 No. 10 October 2013, The Department of Qur'an and Sunnah Studies, Kulliyyah of Islamic Revealed KnowledgeInternational Islamic University Malaysia Kuala Lumpur

Green, S. D., \& Sergeeva, N. (2019). Value creation in projects: Towards a narrative perspective. International Journal of Project Management, 37(5), 636-651. https://doi.org/10.1016/j. ijproman.2018.12.004

Jamal, Ahmad, Aqilah Yaccob, Boris Bartikowski, \& Stephanie Slater. (2019). Motivations to donate: Exploring the role of religiousness in charitable donations. Journal of Business Research, (xxxx), 0-1. $\quad$ https://doi.org/10.1016/j. jbusres.2019.01.064

Jang, J., \& Kang, B. B. (2019). Securing a communication channel for the trusted execution environment. Computers and Security, 83, 79-92. https://doi. org $/ 10.1016 / j$.cose. 2019.01 .012

John Nisbitt dan Patrisia Abuderne (dalam Zulkifli, 2007): Jurnal Multi Kultural dan Multi Religius Harmoni, Balitbang \& Diklat Depag RI)

Kamimura, R. (2019). SOM-based information maximization to improve and interpret multi-layered neural networks: From information reduction to information augmentation approach to create new information. Expert Systems with Applications, 125, 397-411. https:// doi.org/10.1016/j.eswa.2019.01.056

Lewis, S. (2015). Qualitative Inquiry and Research Design: Choosing Among Five Approaches. Health Promotion Practice, 16(4), 473-475. https://doi. org/10.1177/1524839915580941
Muhammad Fauzi bin Othman, (2014), Infusion Of Islamic Values In The Malaysian Cicil Service: A Prelude To Islamic HRD? Jurnal of Islamic Sciences and Humanities, Vol.4, hal.31, Al'AbqoriUniversitasSains Islam Malaysia.

Najati, Muhammad Utsman (1992), AlQur'an wa Ilmu An-Nafs, Dar AsySyuruq, Kairo Mesir,

Ridla, Muhammad Rasyid, (1373 H), Tafsir al-Qur'ani al-Hakim, (TafsirAl-manar: I:52), Kairo: DaarulManar.

Schnabel, L. (2018). More religious, less dogmatic: Toward a general framework for gender differences in religion. Social Science Research, 75, 58-72. https://doi. org/10.1016/j.ssresearch.2018.06.010

Statuta, Pedoman dan Laporan, Unisba Unisba (1958 - 2016)

Warren, Neil C. 1977. Empirical Studies in the Psychology of Religion "An Assesment of Period 1960-1970", dalam H. Newton Malony (ed), Cureent Perspektives in the Psychology of Religion, (Eerns, Grand Rapid,)

Yamaguchi, Yohei. (2018). A practicetheory-based analysis of historical changes in household practices and energy demand: A case study from Japan. Technological Forecasting and Social Change, (January), 0-1. https:// doi.org/10.1016/j.techfore.2018.01.032

You, S., Yoo, J. E., \& Koh, Y. (2019). Religious practices and mental health outcomes among Korean adults. Personality and Individual Differences, 142(January), 7-12. $\quad$ https://doi.org/10.1016/j. paid.2019.01.026

Zedan, Ashraf. M., Mohd Yakub Zulkifli Bin Mohd Yusoff, \& Mr. Roslan Bin Mohamed, (2015). An Innovative Teaching Method in Islamic Studies: The Use of Power Point in University of Malaya as Case Study. Procedia - Social and Behavioral Sciences, 182, 543-549. https://doi. org/10.1016/j.sbspro.2015.04.776 